\title{
CLIC4 wt Allele
}

National Cancer Institute

\section{Source}

National Cancer Institute. CLIC4 wt Allele. NCI Thesaurus. Code C51089.

Human CLIC4 wild-type allele is located in the vicinity of 1 p36.11 and is approximately 32 $\mathrm{kb}$ in length. This allele, which encodes chloride intracellular channel protein 4, is involved the regulation of fundamental cellular processes including stabilization of cell membrane potential, trans-epithelial transport, maintenance of intracellular $\mathrm{pH}$, and the regulation of cell volume. 